\title{
USE OF AGRICULTURAL SERVICES IN EUROPEAN UNION COUNTRIES
}

\author{
Małgorzata Kołodziejczak, $\mathrm{PhD}^{1}$ \\ Faculty of Economics and Social Sciences, Poznań University of Life Sciences
}

\begin{abstract}
The purpose of this paper is to assess the use of agricultural services in European Union countries in the context of selected features of agriculture. The Ward's Method was used to isolate six typological clusters of European Union countries. It may be noticed that clusters with a high levels of fixed capital consumption and total intermediate consumption are characterized by a higher use of services than other clusters. The absence of a noticeable relation between the share of crop output in the structure of agricultural output, or between the labour input and the use of agricultural services can be explained by differences in natural conditions, traditional farming models and preferences in choosing between developing the farm's own machinery or using services.
\end{abstract}

Keywords: agricultural services, European Union

JEL codes: O13, Q19

\section{INTRODUCTION}

Substitution takes place in defined boundaries between the following three factors, which make up agricultural production: labour, land and capital; the components of a productive input may also be substituted by one another. In general terms, a farm can achieve a defined production output by combining productive inputs and their components in various ways. Such combinations are determined by price levels of individual inputs that result from the abundance of resources of relevant productive inputs and their components. One of the ways to optimize the production process is to substitute the farm's own labour and capital inputs with procurement of production services. This paper focuses on agricultural services that constitute one of the types of production services in agriculture in individual countries of the European Union ${ }^{2}$. Therefore, the main purpose of this paper is to assess the use of agricultural services of the European Union countries in the context of selected aspects of agriculture.

\section{THEORETICAL BACKGROUND}

According to the EU legislation (Commission Regulation (EC) 138/2004), agricultural services constitute the hire of machines and equipment with corresponding labour. Agricultural services can be divided into two categories: (1) Agricultural services in the form of contract work at the production stage (i.e. agricultural contract work), 'other' agricultural services (the operation of irrigation systems, the design, planting and maintenance of gardens, parks and green areas for sport facilities and the like; tree pruning and

${ }^{1}$ Corresponding author: Wojska Polskiego 28, 60-637 Poznań, Poland, malgorzata.kolodziejczak@up.poznan.pl, +48618466377

${ }^{2}$ The study did not include Cyprus and Malta due to the marginal economic importance of agriculture in those countries. 
hedge trimming, etc.). The term to perform contract work can be misleading, however it is clarified in the following way: contract work (...) may be performed by: (a) specialist contractors for whom these are the principal activities (contractors in the true sense).

Agricultural services support the rationalization of the crop production process: using potential and knowledge of service providers allows to reduce the costs of building and maintaining the farms' own potential as well as to reduce human labour input. Moreover, this is a way to attain higher production efficiency and better product quality. Services are also the carriers of knowledge and of progress in the organization of production and technologies implemented. Therefore, they enable limiting the adverse environmental impact of crop production, for instance by reducing the intensity of soil structure degradation (more sophisticated machines require a smaller number of operations) or by a better selection that results in using less herbicides and pesticides. Although agricultural services alone directly involve crop production processes, their significance goes beyond that. When properly used, they become a part of the process that ushers the shift from traditional and industrial agriculture towards sustainable agriculture.

A large labour force a shortage of capital is a situation which mostly favours the exploitation of the productive input present in abundant quantity, i.e. labour. In such conditions, capital costs, including service procurement, are lower and often limited to activities that increase land productivity (i.e. fertilization and wide use of chemicals). Having in mind the need to ensure further growth of agricultural output, a decrease in the farming labour resources and an increase in their costs results in an increased importance of capital inputs, especially those that allow for labour efficiency to be improved, e.g. by equipping the workforce with machinery and agricultural equipment. However, improving the farms' equipment with fixed assets increases the demand for production services related to the manu- facturing, use and employment of those assets in the production processes (i.e. renovation, maintenance and repair services). At the same time, allocating some capital inputs to services used in the production process (instead of the farm's own assets), leads to a decrease in production costs which is consistent with the commitment to attain economies of production scale and to improve the farm's economic performance ${ }^{3}$.

\section{MATERIALS AND METHODS}

To assess the use of agricultural services in individual EU countries in the context of selected features of agriculture, the countries were grouped by intra-cluster variation with the use of agglomerative hierarchical clustering ${ }^{4}$. The Ward's method was among many different hierarchical methods as it is widely recognized for its outstanding efficiency (Sokołowski, 2002). The more similar are the items, the sooner they may be connected with one another (the minimization of the sum of squared deviations of any two clusters that can be formed at any stage) (Sokołowski, 2002). In the case of research presented in this paper, this method allowed to identify clusters of countries with similar characteristics in terms of estimated variables; this can be helpful when drawing conclusions on variables that characterize and/or determine the use of agricultural services. The Euclidean distance was used for clustering purposes $^{5}$ and variance analysis was then performed:

$$
\text { distance }(x, y)=\left\{\sum i\left(x_{i}-y_{i}\right)^{2}\right\}^{1 / 2}
$$

The clusters are put in hierarchical order so that lower-rank clusters are included in upper-rank clusters, in line with the hierarchy of similarity between items (Pawlak, 2008; after Marek, 1989). Considering the fact that non-correlated features have the greatest influence on the clustering process (Błażejczyk-Majka and Kala, 2005), the calculated indicators were assessed for correlation coefficients; the variables were standardized first.

${ }^{3}$ cf. Cieśla, Kowalska-Grudzień and Kruczek-Patko (1987).

${ }^{4}$ Clustering, as a method of putting items in order is an essential process to be used when studying economic phenomena (Błażejczyk-Majka and Kala, 2005).

${ }^{5}$ The Euclidean distance is one of the most frequently used methods for items characterized by measurable features (Marek; 1989; Pawlak and Poczta, 2011; after Mardia, Kent and Bibby, 1979). 
The selected features that characterize the agriculture of individual EU countries were taken into consideration in the clustering process. A series of attempts to develop a typology based on various sets of features were carried out. The set of features presented in this paper turned out to be the only one that complied with both substantive and statistical selection criteria. After eliminating strongly correlated variables ${ }^{6}$, the typology was created with the use of the following indicators that characterize and/or determine the use of agricultural services in agriculture of individual countries of the European Union:

- $x_{1}-$ value of agricultural services per hectare of agricultural land (EUR),

- $x_{2}-$ Annual Work Unit (AWU) input per farm,

- $x_{3}$ - agricultural service intensity rate (EUR per EUR 1,000 worth of crop output),
- $x_{4}$ - fixed capital consumption per hectare of agricultural land (EUR),

- $x_{5}$ - total intermediate consumption per hectare of agricultural land (EUR),

- $x_{6}-$ share of crop output in agricultural output (\%). The features that characterize the identified typological clusters are based on the values of measure of differences between means of active features (Wysocki, 2010).

Dana from the Statistical Office of the European Union for 2004-2017 and publications on the subject in question were used to perform the calculations.

\section{RESULTS AND DISCUSSION}

As a result of the clustering process that included a stepby-step diagram ${ }^{7}$, six relatively homogenous clusters of EU countries were obtained (Fig. 1, Tables 1 and 2).

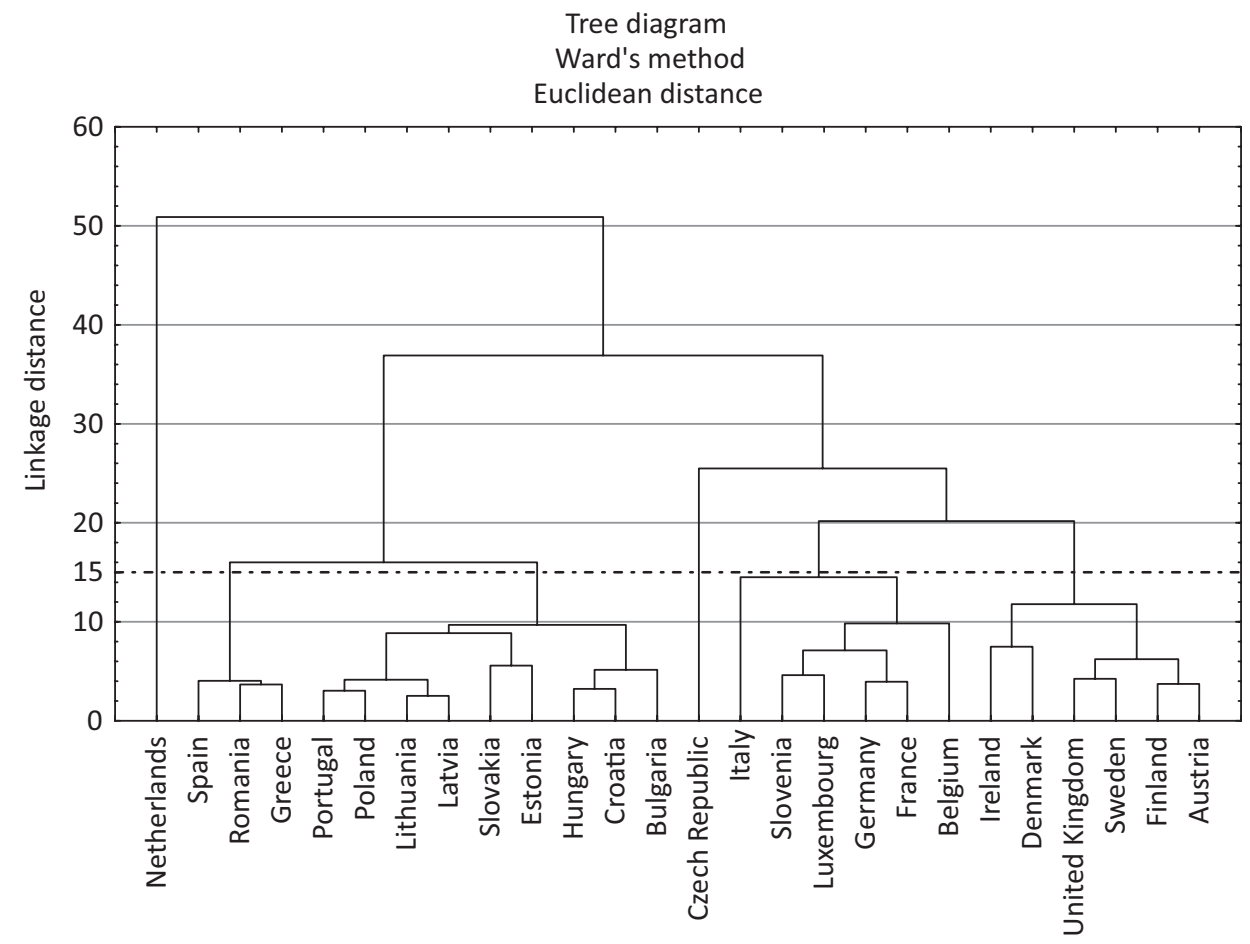

Figure 1. Tree diagram of the EU countries by the use of services and by characteristics of agriculture Source: Eurostat (online data). Retrieved: http://ec.europa.eu/eurostat/data/database [Accessed 18.05.2018], own calculations.

${ }^{6}$ The correlation of the initial set of features was analyzed. Afterwards, highly correlated features were eliminated.

${ }^{7}$ The tree diagram was cut at the 15th level. This is where many clusters were formed within a very short linkage distance. According to Błażejczyk-Majka and Kala (2005) and Stanisz (2007), the diagram of the agglomeration process may indicate the cutting place of the tree diagram. Usually, it coincides with the place where a clear flattening is visible. 
Proceedings of the 2018 International Scientific Conference 'Economic Sciences for Agribusiness and Rural Economy' No 1, Warsaw, 7-8 June 2018, pp. 364-369

Table 1. Intra-cluster mean values of active features describing the use of services and characterizing agriculture countries of the European Union

\begin{tabular}{|c|c|c|c|c|c|c|c|}
\hline \multirow{2}{*}{ Specification } & \multicolumn{6}{|c|}{ Class } & \multirow{2}{*}{ Mean } \\
\hline & I & II & III & IV & $\mathrm{V}$ & VI & \\
\hline $\begin{array}{l}\text { Value of agricultural services per } 1 \text { ha } \\
\text { of agricultural land (EUR) }\end{array}$ & 1285 & 20.7 & 40.9 & 30.8 & 90.2 & 80.4 & 56.5 \\
\hline $\begin{array}{l}\text { Service intensity rate } \\
\text { (value of agricultural services } \\
\text { per EUR 1,000 worth of crop output) }\end{array}$ & 187 & 19.8 & 62.6 & 42.5 & 68.5 & 122.4 & 80.7 \\
\hline $\begin{array}{l}\text { Share of crop output in the structure } \\
\text { of agricultural output }(\%)\end{array}$ & 50.3 & 68.3 & 55.4 & 57.0 & 50.3 & 37.9 & 52.3 \\
\hline Annual Work Unit (AWU) per farm & 2.0 & 0.6 & 1.1 & 3.8 & 1.4 & 1.1 & 1.1 \\
\hline $\begin{array}{l}\text { Fixed capital consumption per } 1 \text { ha } \\
\text { of agricultural land (EUR) }\end{array}$ & 1788 & 220 & 114 & 163 & 566 & 431 & 251.3 \\
\hline $\begin{array}{l}\text { Total intermediate consumption per } 1 \text { ha } \\
\text { of agricultural land (EUR) }\end{array}$ & 8633 & 861 & 801 & 931 & 1788 & 1322 & 1134.6 \\
\hline
\end{tabular}

Source: Eurostat (online data). Retrieved: http://ec.europa.eu/eurostat/data/database [Accessed 22.04.2018], own calculations.

Table 2. Values of measure of differences between means of features describing the use of services and the characteristics of agriculture in countries of the European Union and in classes thereof (Ward's method)

\begin{tabular}{|l|c|c|c|c|c|c|}
\hline \multirow{2}{*}{ Specification } & \multicolumn{5}{|c|}{ Class } & VI \\
\cline { 2 - 6 } & I & II & III & IV & V & 0.8 \\
\hline $\begin{array}{l}\text { Value of agricultural services per 1 ha } \\
\text { of agricultural land (EUR) }\end{array}$ & 43 & -1.3 & -0.6 & -0.9 & 1.2 & 1.3 \\
\hline $\begin{array}{l}\text { Service intensity rate } \\
\text { (value of agricultural services per } \\
\text { EUR 1,000 worth of crop production) }\end{array}$ & 3.4 & -1.9 & -0.6 & -1.2 & -0.4 & -2.0 \\
\hline $\begin{array}{l}\text { Share of crop output in the structure } \\
\text { of agricultural output (\%) }\end{array}$ & -0.3 & 2.3 & 0.4 & 0.7 & -0.3 & 0.0 \\
\hline $\begin{array}{l}\text { Annual Work Unit (AWU) } \\
\text { per 1 agricultural holding }\end{array}$ & 3.2 & -2.1 & -0.1 & 10.0 & 0.9 & 1.0 \\
\hline $\begin{array}{l}\text { Fixed capital consumption per 1 ha } \\
\text { of agricultural land (EUR) }\end{array}$ & 8.6 & -0.2 & -0.8 & -0.5 & 1.8 & 0.5 \\
\hline $\begin{array}{l}\text { Total intermediate consumption per 1 ha } \\
\text { of agricultural land (EUR) }\end{array}$ & 21.7 & -0.8 & -1.0 & -0.6 & 1.9 \\
\hline
\end{tabular}

Source: own calculations based on Table 1 .

The first type of cluster (I) was a singleton composed of the Netherlands. This type is characterized by the greatest value of agricultural services per hectare of agricultural land (EUR 1,285), the highest service intensity rate of agricultural production (EUR 187/
EUR 1,000 worth of crop output), the highest number of AWU per farm (2 AWU) and the highest level of fixed capital consumption and total intermediate consumption per hectare of agricultural land (EUR 1,788 and EUR 8,633, respectively). Apart from that, the 
share of crop output in the structure of agricultural output of this country came to $50 \%$.

The second typological cluster (II) included Spain, Romania and Greece. Agriculture in this type of countries is characterized by the lowest value of agricultural services per hectare of agricultural land (EUR 20.7) and per EUR 1,000 worth of crop output (EUR 19.8). Also, this cluster exhibited the lowest number of AWU per farm (0.6). A characteristic feature of this cluster is the highest share of crop output in the structure of agricultural output (nearly $70 \%$ ).

The third cluster (III) included eight Central and Eastern European countries (including four Baltic countries: Poland, Lithuania, Latvia, Estonia, followed by Slovakia, Hungary, Croatia and Bulgaria) and Portugal. In these countries, the agriculture is characterized by the lowest value of the total intermediate consumption per 1 ha of agricultural land (EUR 801 ). The value of services per hectare and the value of services per EUR 1,000 worth of crop output was higher in those countries than in clusters II and IV.

The fourth type (IV) consisted of only one country, the Czech Republic. The agriculture of this type is characterized by the greatest number of AWU per farm (almost 4 AWU) and a low value of agricultural services per EUR 1,000 worth of crop output (EUR 42.5). It is the result of a large average area of farms in the Czech Republic and of agricultural production being based mostly on own machinery and equipment. In this country, large farms continue the tradition of state-owned farms and production cooperatives that were active before 1990. This has many consequences, including tying up a relatively large amount of labour resources.

The fifth cluster (V) included six countries: Italy, Slovenia, Luxembourg, Germany, France and Belgium. A characteristic feature of agriculture in this cluster is a high agricultural services per hectare of agricultural land and a very high level of fixed capital consumption and total intermediate consumption per hectare of agricultural land, reaching EUR 431 and EUR 1,788, respectively.

The sixth typological cluster consisted of six Western European countries: Ireland, Denmark, the United Kingdom, Sweden, Finland and Austria. This cluster is characterized by a very high service inten- sity rate of agricultural production (EUR 122.4 per EUR 1,000 worth of crop output), a high value of fixed capital consumption per hectare of agricultural land (EUR 251.3), and the lowest share of crop output in the structure of agricultural output.

\section{CONCLUSIONS}

The clustering procedure resulted in identifying six clusters of EU country type that differ from each other by the use of services and by selected agricultural characteristics. Although the population surveyed demonstrates a varying share of crop output in the structure of agricultural output, it is difficult to find any relation between that diversity and the use of services. Surprisingly, this is also true for the amount of labour inputs. In cluster IV, large labour inputs are accompanied by a relatively small use of services (note however that this is a singleton, the Czech Republic). The values obtained in other clusters do not indicate the existence of, for instance, a substitution between labour inputs and procurement of agricultural services. The absence of a clear relation between the share of crop output in the structure of agricultural output and the amount of labour inputs, on one side, and the use of services, on the other side, can be explained by differences in natural conditions, traditional farming models and preferences in choosing between the developing the farm's own machinery and using services. On the other hand, it may be noticed that groups characterized by high levels of fixed capital consumption and total intermediate consumption also demonstrate a higher service output compared to other clusters.

\section{REFERENCES}

1. Błażejczyk-Majka, L., Kala, R. (2005). Metody analizy skupień do charakterystyki użytków rolnych wybranych państw Unii Europejskiej [Methods of cluster analysis for characterizing agricultural land of selected countries of the European Union]. Roczniki Naukowe SERiA 7 (5), pp. 5-8.

2. Ciesla, S., Kowalska-Grudzien, A., Kruczek-Patko, A. (1987). Rynek środków produkcji i uslug dla rolnictwa [Domestic market of means and services for agricultural]. Wydawnictwo Akademii Ekonomicznej w Krakowie, Kraków. 
3. Mardia, KV., Kent, J.T., Bibby, J.M. (1979). Multivariate analysis. Academic Press, London.

4. Marek, T. (1989). Analiza skupień w badaniach empirycznych. Metody SAHN [Cluster analysis in empirical research. SAHN methods]. PWN, Warszawa.

5. Pawlak, K. (2008). Analiza i model rozwoju handlu zagranicznego produktami rolno-spożywczymi [Analysis and development model of foreign trade in agri-food products]. In: Urban, R. (ed.) Wpływ integracji z Unią Europejską na polską gospodarką [Impact of integration with the European Union on the Polish economy]. IERiGZ PIB, Warszawa, p. 45.

6. Pawlak, K., Poczta, W. (2011). Międzynarodowy handel rolny. Teorie, konkurencyjność, scenariusze rozwoju [International agricultural trade. Theories, competitiveness, development scenarios]. PWE, Warszawa.
7. Stanisz A. (2007) Przystępny kurs statystyki z zastosowaniem STATISTICA PL na przykładach z medycyny. Analizy wielowymiarowe [An accessible statistics course based on STATISTICA.PL illustrated by medical examples. Multidimensional analyses]. Vol. 3. StatSoft, Kraków.

8. Sokołowski, A. (2002). Metody stosowane w data mining [Data mining methods]. StatSoft Polska. Retrieved from: https://media.statsoft.pl/_old_dnn/downloads/metody_stosowane_w_data_mining.pdf [Accessed 22.04.2018].

9. Wysocki, F. (2010). Metody taksonomiczne w rozpoznawaniu typów ekonomicznych rolnictwa i obszarów wiejskich [The methods of taxonomy for recognition of economic types in agriculture and rural areas]. Wydawnictwo Uniwersytetu Przyrodniczego, Poznań. 